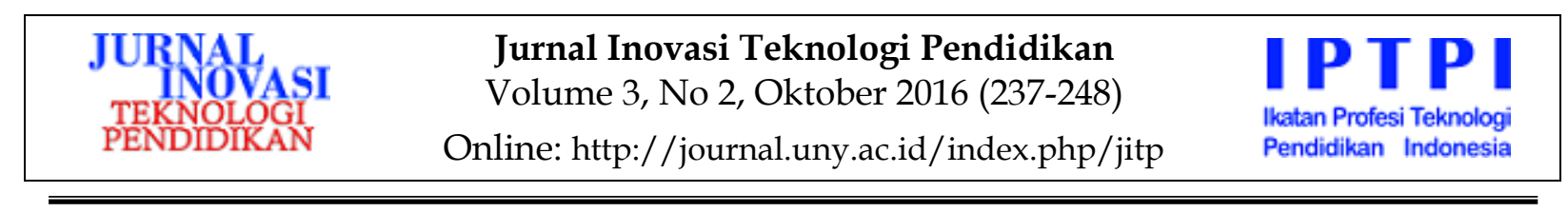

\title{
PENGEMBANGAN MULTIMEDIA INTERAKTIF UNTUK PEMBELAJARAN DESAIN BUSANA DI SMK
}

\author{
Purwosiwi Pandansari, Abdul Gafur \\ SMK Negeri 1 Sewon Bantul, FIS Universitas Negeri Yogyakarta \\ sari.pandansari@gmail.com, abdul_gafur@uny.ac.id
}

\begin{abstract}
Abstrak
Penelitian ini bertujuan untuk: (1) menghasilkan produk multimedia pembelajaran yang interaktif untuk peserta didik jurusan busana SMK Negeri 1 Depok, (2) menentukan kelayakan produk multimedia interaktif untuk peserta didik jurusan busana butik yang digunakan dalam pembelajaran desain busana, (3) menguji efektivitas multimedia interaktif untuk mata pelajaran mendesain busana. Penelitian ini adalah penelitian pengembangan (R\&D) adaptasi model Alessi dan Trollip. Prosedur pengembangan meliputi tahap perencanaan, desain, dan pengembangan. Validasi oleh ahli media dan ahli materi untuk menguji produk dan mengeliminasi permasalahan prosedur, kesesuaiannya dengan tujuan, dan alur petunjuk penggunaan multimedia sesuai pembelajaran desain busana. Kelayakan mencapai skor 4,64 dengan kategori "sangat baik" untuk materi dan untuk media mencapai skor 4,16 dengan katagori "sangat baik" dan peserta didik dengan nilai rata-rata 4,54, Multimedia interaktif pembelajaran desain busana untuk kelas XI SMK Negeri 1 Depok efektif memotivasi kreativitas yang dimiliki peserta didik diketahui dari hasil belajar sebelum menggunakan multimedia dengan rata-rata nilai 72,4 dan hasil belajar setelah menggunakan multimedia rata-rata nilai 86,2.
\end{abstract}

Kata kunci: multimedia, desain busana

\section{DEVELOPING INTERACTIVE LEARNING MULTIMEDIA FOR FASHION DESIGN AT SMK}

Purwosiwi Pandansari, Abdul Gafur

SMK Negeri 1 Sewon Bantul, FIS Universitas Negeri Yogyakarta sari.pandansari@gmail.com, abdul_gafur@uny.ac.id

\begin{abstract}
This study aims to: (1) produce interactive learning multimedia which include design, material, display, and programming for students majoring in fashion SMK Negeri 1 Depok, (2) determine the feasibility of Interactive Multimedia covering aspects of the display, programming and material for Learners Department Clothing Boutique used in learning fashion design, and (3) Find out the effectiveness of Interactive Multimedia for learning fashion design. This type of research is research development $(R \in D)$ adapted from Alessi and Trollip models. The development procedure includes the planning, design, and development. Validation was done by expert media and materials experts to examine the feasibility of multimedia products and eliminate the problems procedures, suitability to the purpose, and the flow of instructions for use in accordance with learning multimedia for fashion design. The feasibility of achieving a score of 4.64 is in the "very good" category for the material and for the media reaches a score of 4.16 in the "very good" category and learners with an average value of 4.54. interactive learning multimedia fashion design for class XI SMK 1 Depok effectively motivates creativity of learners known from prior use of multimedia learning out comes with an average value of 72.4 and learning outcomes after using multimediathe average value 86.2.
\end{abstract}

Keywords: multimedia, fashion design 


\section{Pendahuluan}

Misi pembangunan di bidang pendidikan ditunjukkan untuk mengadakan perubahan dan pembaharuan dari masa ke masa dengan memperbaiki pola pembelajaran agar menjadi lebih baik. Salah satunya SMK, pendidikan Sekolah Menengah Kejuruan pada dasarnya diselenggarakan agar mempersiapkan tenaga kerja terampil tingkat menengah untuk mendukung pembangunan sebagai sektor perekonomian bangsa.

Secara spesifik pendidikan SMK diselenggarakan untuk: (1) melakukan transformasi status peserta didik, dari manusia "beban" menjadi manusia "aset"; (2) mempersiapkan sumber daya manusia yang memiliki keunggulan komparatif (comparative advantage) dan kompetitif (competitive advantage) bagi pembangunan sektor industri dan sektor-sektor ekonomi lainya di Indonesia; (3) memberi bekal bagi peserta didik untuk berkembang secara berkelanjutan (Direktorat Pembinaan SMK, 2006, p.3).

Sekolah Menengah Kejuruan (SMK) sebagai pencetak tenaga kerja yang siap dalam dunia kerja perlu dibekali dengan pengetahuan dan keterampilan yang sesuai dengan kompetensi keahlian masing-masing. Maka kualitas kegiatan belajar mengajar semestinya juga harus ditingkatkan secara terus menerus untuk mencapai tujuan dalam proses belajar mengajar.

Mata pelajaran mendesain busana di SMK Negeri 1 Depok, jurusan busana butik mengajarkan mata pelajaran mendesain busana yang harus ditempuh oleh peserta didik karena mendesain suatu busana biasanya dibuat terlebih dahulu dalam suatu sketsa busana dari sektsa tersebut terciptalah gambar-gambar desain busana yang dapat memberi gambaran riil (nyata). Menurut Sumaryati, Catri dan Winarti (2013.p19) desain secara umum adalah perencanaan yang dapat dituangkan melalui gambar atau langsung kepada bentuk benda sebagai sasarannya, atau dapat pula disimpulkan bahwa desain adalah suatu rancangan yang terdiri dari beberapa un- sur untuk mewujudkan suatu hasil yang nyata. Blandine, (2014, p.8) mengungkapkan bahwa " Each drawing tool has its own set of Quirks and elimtations, which makes it more or less suited to a particular style". Bestari, (2011, p.iii) juga menyampaikan bahwa desain suatu busana biasanya dituangkan lebih dahulu dalam suatu seketsa busana, sekesta tercipta adalah gambargambar desain busana yang dapat memberi gambaran riil. Dalam pelajarannya peserta didik diharapkan mampu membuat macam-macam gambar busana sesuai dengan menerapkan unsur dan prinsip desain, siluet desain yang di-mulai dari sketsa sampai finishing serta metode mendesain busana dengan berbagi teknik pewarnaan yang mengunakan pensil warna, krayon, atau pastel, cat air, cat akrilik, dan lain-lain sehingga peserta didik dilatih mengasah keterampilan dalam mengembangkan ide-ide mendesain busana dan peserta didik dilatih membuat gambar atau sektsa busana dengan kreativitas yang dimiliki.

Hasil pengamatan di kelas busana butik dalam pembelajaran mendesain busana ada beberapa masalah yang dimiliki peserta didik dalam mengerjakan tugas mendesain busana, adanya buku pelajaran tidak begitu membantu karena satu buku untuk 2 peserta didik maka harus bergantian untuk menggunakannya. Hal itu membuat peserta didik menjadi kurang fokus memahami isi dari buku dan penjelasan guru, oleh sebab itu peserta didik hanya mencontoh gambar yang ada di slide Microsoft Power Point atau mencontoh buku sewaktu pembelajaran menggambar busana, selain itu banyak bentuk dan jenis dari ragam busana yang dapat peserta didik gambarkan namun banyak gambar yang sama bentuknya itu menjadikan kurang memotivasi kreativitas peserta didik dalam mendesain busana. Teknik merwarnai dalam mendesain busana pun masih belum diterapkan dengan baik sehingga peserta didik masih kurang memahami bentuk siluet desain yang peserta didik gambarkan, penerapan unsur dan prinsip desain masih 
belum diterapkan dengan baik maka sering tugas yang diberikan tidak selesai tepat waktu.

Kemajuan dalam bidang teknologi saat ini, dapat diibaratkan seperti air bah yang tak dapat dibendung. Keadaan ini tentu banyak membawa manfaat dalam kehidupan sehari-hari, meskipun tentu ada dampak kurang baik pada sisi lain dalam penggunaannya. Salah satu manfaat bidang teknologi tersebut antara lain bidang pendidikan, para pendidik dan peserta didik dapat memanfaatkan kecanggihan teknologi, baik teknologi informasi maupun teknologi komunikasi agar proses pembelajaran dapat lebih menarik dan menyenangkan, terutama peserta didik dapat fokus dalam pembelajaran.

Pengembangan multimedia pembelajaran ini tidak lepas dari peran teknologi pembelajaran yaitu teori dan praktek dalam desain, pengembangan, pemanfaatan, pengelolaan serta evaluasi proses dan sumber untuk belajar. Jadi, Penelitian tentang pengembangkan multimedia pembelajaran termasuk dalam salah satu kawasan teknologi pembelajaran, yaitu pada kawasan pengembangkan (Development). Tujuan dalam penilitian ini (a) menghasilkan produk multimedia pembelajaran yang interaktif untuk peserta didik jurusan busana SMK Negeri 1 Depok; (b) menentukan kelayakan produk Multimedia Interaktif untuk Peserta didik Jurusan busana yang digunakan dalam pembelajaran mendisain busana; (c) mengetahui efektivitas multimedia interaktif untuk mata pelajaran mendisain busana.

Teknologi pembelajaran menerapkan prinsip-prinsip ilmu pengetahuan dalam menyelesaikan permasalahan belajar, pandangan ini mengasumsikan bahwa ilmu dan teknologi tidak dapat terpisah (AECT, 1994, p.6). Smaldino, Russel, dan Molenda, (2004, p.9) mendefinisikan sebagai berikut: "Educational technology is the study and ethical practice of facilitating learning and improving performance by creating, using, and managing appropriate technological processes and resources."
Berkembangnya ragam teknologi informasi dan komunikasi saat ini memberikan pengaruh baik secara langsung maupaun tidak langsung terhadap kualitas pembelajaran di sekolah. Namun pada kenyataanya kualitas dan tujuan pembelajaran belum maksimal dan masih rendah, rendahnya kualitas pembelajaran secara umum dapat dilihat dari 2 sisi yaitu sisi proses dan sisi hasil yang pertama dari sisi proses berkaitan dengan permasalahan yang terjadi di dalam kelas, sedangkan yang kedua dari sisi proses berkaitan dengan rendahnya hasil belajar siswa setelah mengikuti pembelajaran selama kurun waktu tertentu.

Teori behavioristik, belajar adalah perubahan tingkah laku sebagai akibat dari adanya interaksi stimulus dan respon, dengan kata lin belajar merupakan bentuk perubahan yang dialami siswa dalam hasil interaksi antara stimulus dan respon (Budiningsih, 2005, p.420). Tujuan dari behavioral terkait dengan perilaku adalah peryataan-peryataan yang jelas tentang hasil yang dikendaki dari peross belajar peserta didik.

Tujuan semacam itu dapat berkisar dari yang umum ke spesifik, seperti "meningkatkan kesadaran peserta didik" dapat dipenuhi oleh seluruh jenis pengajaran. Sebaliknya tujuan yang terlalu sepesifik dan yang mendokumentasikan setiap detail perilaku peserta didik akan menghabiskan waktu dan dapat menyebabkan guru tidak bisa melihat hasil-hasil pembelajaran yang paling penting. Tujuan yang bagus untuk mengetahui sebuah tujuan behavioral (1) mengelompok peserta didik yang spesifik; (2) perilaku-perilaku aktual yang harus dijalankan peserta didik sebagai akibat aktivitas-aktivitas pengajaran; (3) kondisi dalam menilai perilaku peserta didik akan menjalakan perilaku tersebut; (4) keriteria dalam menilai perilaku-perilaku perserta didik untuk mengetahui apakah tujuan yang ditentukan terpenuhi dan tercapai. Guthrie (Budingsih, 2015, p.445) menjelaskan bukan mengimplikasikan bahwa begitu peserta didik berhasil menyelesaikan sebuah soal atau menulis tentang artikel 
penelitaian, peserta didik akan menguasai keterampilan yang di syaratkan sebagai tindakan. Latihan-latihan soal akan menghubungkan berbagai gerakan yang terlibat dalam tindakan-tindakan dari mengerjakan soal-soal latihan maka peserta didik harus dilatih untuk membetuk perilaku-perilaku agar juga menemukan situasi-situasi dari perlilaku tersebut bisa menyesuaikan.

Teori belajar kognitif lebih mementingkan proses belajar dari pada hasil belajarnya juga menekankan bahwa bagianbagian dari suatu situasi saling berhubungan dengan seluruh konteks situasi tersebut. Teori ini berpandangan bahwa belajar merupakan suatu proses internal yang mencakup ingatan,retensi, pengolahan informasi, emosi, dan aspek-aspek kejiwaan lainya. Menurut Degeng (2012, p.95) strategi kognitif untuk peserta didik yang telah belajar apabila ia telah mengembangkan cara-cara untuk meningkatkan keefektifan dan efisiensi proses berpikir dalam proses belajarnya. Demikian juga, apabila peserta didik belajar secara mandiri.

\section{Tabel 1. Tiga Asumsi Teori Kognitif}

\begin{tabular}{|c|c|c|}
\hline Asumsi & Deskripsi & Kutipan terkait \\
\hline Saluran-ganda & $\begin{array}{l}\text { Manusia memiliki saluran } \\
\text { terpisah untuk memproses } \\
\text { informasi visual dan informasi } \\
\text { auditori }\end{array}$ & $\begin{array}{l}\text { Paivo, 1986; } \\
\text { Baddeley. } 1992\end{array}$ \\
\hline $\begin{array}{l}\text { Kapasitas- } \\
\text { terbatas }\end{array}$ & $\begin{array}{l}\text { Manusia punya keterbatasan } \\
\text { dalam jumlah informasi yang } \\
\text { bisa masing-masing saluran } \\
\text { pada waktu yang sama }\end{array}$ & $\begin{array}{l}\text { Baddeley. } 1992 \\
\text { Chandler dan } \\
\text { Sweller, } 1991\end{array}$ \\
\hline $\begin{array}{l}\text { Pemrosesan- } \\
\text { aktif }\end{array}$ & $\begin{array}{l}\text { Manusia melakukan } \\
\text { pembelajaran aktif dengan } \\
\text { memilih informasi masuk yang } \\
\text { relevan, mengorganisasikan } \\
\text { informasi-informasi itu ke } \\
\text { dalam repersentasi mental } \\
\text { yang koheren dan memadukan } \\
\text { reprentasi mental itu dengan } \\
\text { pengetahuan lain }\end{array}$ & $\begin{array}{l}\text { Mayer, } 1999 \\
\text { Wittrock. } 1989\end{array}$ \\
\hline
\end{tabular}

Pada dasarnya pembelajaran yang berlangsung di kelas dengan menggunakan multimedia akan berefek efektivitas pembelajaran menurut Miarso (2007, p.545). Pembelajaran merupakan suatu usaha sadar yang disengaja, bertujuan, dan terkendali agar orang lain belajar, atau terjadi perubahan yang relatif menetap pada diri orang tersebut, yang dilakukan oleh seseorang atau tim yang memiliki kemampuan dan kompetensi dalam merancang dan mengembangkan sumber belajar yang diperlukan.

Perkembangan ilmu pengetahuan dan teknologi semakin mendorong upayaupaya pembaharuan dalam pemanfaatan hasil-hasil teknologi dalam proses belajar (Arsyad, 2009, p.2). Program Macromedia Flash akan membuat peserta didik dapat mengamati dan memilih aplikasi atau menu yang ada di dalam program untuk mengembangkan ilmu dan kreativitasnya dalam desain busana. Program Macromedia Flash adalah Software program yang ditunjukkan oleh pengembang multimedia yang bermaksud untuk merancang animasi, pembuatan halaman web, presentasi bertujuan untuk bisnis maupun proses pembelajaran. Kelebihan dari Flash merupakan aplikasi animasi web yang sangat populer saat ini, Flash dapat mengimpor hampir semua gambar dan file-file audio sehingga dapat lebih hidup, dan pengembang dapat membuat animasi sesuai dengan desain media yang akan dibuat.

Kekurangan media flash adalah peserta didik menjadi tidak bisa bersosialisasi dengan teman sebangku. Menurut Yudhiantoro (2006, p.39) kelebihan bahan ajar berbasis komputer menayangkan informasi dalam bentuk teks dan grafik, interkatif dengan peserta didik, dapat mengelola laporan atau respon peserta didik, dapat diadaptasi sesuai kebutuhan peserta didik, dapat mengontrol hardware media lain, dan dapat dihubungkan dengan video untuk mengawasi kegiatan belajar peseta didik. Sedangkan kekurangan dari media ini adalah memerlukan komputer dan pengetahuan program, membutukan hardware khusus untuk proses pengembangan dan penggunaannya, resolusi untuk gambar grafik sangat terbatas pada sistem microprocessor, dan hanya efektif digunakan beberapa orang dalam kurun waktu tertentu. Adapun penelitian oleh Rusdewanti dan Gafur (2014) dalam pengembangan media pembelajaran interaktif seni musik untuk 
siswa SMP yang menggunakan multimedia sangat efektif terhadap pembelajaran di kelas terbukti dari hasil uji coba lapangan menunjukkan bahwa aspek pembelajaran masuk kategori baik dengan rata-rata $47,45 \%$ dan aspek media masuk kategori sangat baik dengan rata-rata $48,35 \%$. Penelitian yang dilakukan oleh Verecio (2014) dengan judul penelitian Students' evaluation of An Interactive Multimedia Courseware menujukkan bahwa courseware dikembangkan untuk memfasilitasi dan meningkatkan proses pembelajaran di dalam kelas serta menjaga dan menimbulkan sikap fokus dalam peserta didik belajar. Peningkatan konsistensi peserta didik dalam kemampuan pembelajaran dapat menentukan dan mengukur pencapaian tujuan pembelajaran. Hasil ini bisa mendorong guru dan peneliti dalam mengembangkan coursewares.

Berdasarkan uraian yang telah disampaikan, penelitian ini bertujuan untuk: (1) menghasilkan produk multimedia pembelajaran yang interaktif untuk peserta didik jurusan busana SMK Negeri 1 Depok, (2) menentukan kelayakan produk multimedia interaktif untuk peserta didik jurusan busana butik yang digunakan dalam pembelajaran desain busana, (3) menguji efektivitas multimedia interaktif untuk mata pelajaran mendesain busana.

\section{Metode Penelitian}

Penelitian dan pengembangan yakni Research \& Development (R\&D) yang bertujuan untuk menghasilkan produk, menurut Soenarto (Dwiningrum, 2013, p.186) mengembangkan produk pendidikan dilakukan melalui, (1) studi pendahuluan (preliminary study) tentang produk yang akan dikembangkan, dilakukan pada kondisi kontekstual di lapangan dimana penelitian akan dilakukan, (2) pembuatan produk awal (design product) dan validasi produk melalui uji-coba (expert judgement), uji coba utama dan uji coba lapangan, revisi, dan penyempurnaan produk berorientasi untuk mengembangkan dan memvalidasi produk-produk pendidikan.
Produk yang dikembangkan dalam penelitian ini digunakan untuk mengatasi permasalahan dalam pembelajaran di kelas berupa multimedia pembelajaran yang layak untuk mata pelajaran mendesain busana, pada pokok bahasan menggambar busana untuk peseta didik kelas XI jurusan busana berlokasi di SMK Negeri 1 Depok sebagai tempat penelitian dan jurusan teknologi pembelajaran Program Pascasarjana sebagai tempat peneliti mengembangkan produk.

Model pengembangan Alessi dan Trolip (2001, pp.410-413) untuk menciptakan produk media interaktif menggunakan tiga langkah perencanaan, mendesaian, pengembangan. Model ini dipilih karena sesuai dengan model pengembangan yang telah ada. Penelitian diawali dengan melakukan observasi awal di SMK Negeri 1 Depok, Yogyakarta pada Desember 2014 dan penelitian dilaksanakan pada Juli 2015.

Prosedur pengembangan merupakan langkah-langkah yang dilakukan selama penelitian dan pengembangan produk berlangsung sebagai berikut. Tahap 1 adalah studi pendahuluan. Tahap ini dilakukan dua tahapan kegiatan diantaranya adalah: (a) melakukan studi pustaka, yaitu berupa kegiatan dalam hal untuk mengumpulkan informasi berkaitan dengan bahanbahan pustaka yang dapat menunjang dalam pengembangan produk, seperti: mempelajari jurnal atau laporan hasil penelitian tentang penggunaan multimedia interaktif dalam pembelajaran, mempelajari bukubuku teks asing maupun lokal terkait dengan teori pengembangan multimedia interaktif; (b) melakukan studi lapangan yaitu suatu kegiatan yang dilakukan untuk mengetahui kebutuhan para peserta didik dan pendidik tentang materi atau pokok bahasan dalam pembelajaran mendesain busana yang dirasa masih abstrak bila hanya dijelasakan atau dipahami dan untuk mengetahui jenis media seperti apa yang sesuai dikembangan melalui pra survei dengan penyebaran kuesioner analisis kebutuan kepada peserta didik dan pendidik serta pengamatan langsung di kelas, 
laboratorium komputer, dan dokumen hasil belajar mendesain busana

Tahap 2 adalah Perencanaan. Pada tahap ini kegiatan yang dilakukan adalah: (1) menetukan standar kompetensi (SK) dari materi yang akan mendukung media interaktif; (2) mengidentifikasi karakteristik awal peserta didik agar media interaktif dapat tepat sasaran untuk peserta didik yang merasa kesulitan; (3) melakukan analisis dan memilih materi pembelajaran (KD); (4) menentukan indikator keberhasilan dari pembelajaran mendesain busana; (5) mengembangkan instrumen penilaian; (6) mengembangkan dan memilih materi pembelajaran; dan (7) mengembangkan strategi pembelajaran.

Tahap 3 adalah Desain. Tahap ini merupakan kegiatan perakitan perbagianbagian menjadi produk awal multimedia interkatif dituangkan dalam bentuk $C D$, kegiatan pada tahap pengembangan produk ini diantaranya adalah: (1) membuat flowchart dan storyboard yang dirancang sesuai dengan $\mathrm{SK}, \mathrm{KD}$, materi mendesain busana dari sektsa hingga perwarnaan busana pesta untuk; (2) mengumpulkan bahan-bahan seperti: gambar, materi, video, dan animasi tentang materi mendesain busana; (3) menyiapkan materi pendukung yakni materi yang berkaitan tentang materi mendesain busana seperti pengetahuan dasar busana dan pola busana; (4) menentukan program dengan macromedia flash adalah perangkat software yang cocok untuk pengembangan multimedia interaktif mendesain busana; (5) merakit bahan dan materi menjadi produk, materi dan seluruh bahan dirakit oleh pengembang dengan software macromedia flash karena dari bahan-bahan tersebut dapat tersusun rapi serta mudah untuk diaplikasikan dalam perangkat komputer; (6) menjadikan dalam bentuk $C D$ agar lebih ringkas dan dapat digunakan pada saat tertentu dalam pembelajaran mendesain busana.

Tahap 4 adalah Pengembangan dan evaluasi, dalam tahap evaluasi multimedia interaktif meliputi tiga tahapan evaluasi: evaluasi ongoing adalah evaluasi yang di- lakukan terus menerus oleh pengembang produk dari awal hingga akhir dan bersifat nonformal: 2 evaluasi formatif (uji alpha yang melibatkan ahli materi mendesain busana dan ahli media kemudian dilakukan analisis dan revisi akhir, uji beta yang melibatkan pendidik dan peserta didik kelas XI jurusan busana) dalam pembelajaran mendesain busana menggunakan media interaktif tersebut. Validasi program sumatif yakni pengembangan proses pembelajaran untuk mengetahu efektivitas dari multimedia interaktif tersebut layak dan efektif digunakan dalam pembelajaran dengan unjuk kerja dan koesioner multimedia dari produk multimedia interkatif mendesain busana.

Subjek uji coba/responden dalam penelitian pengembangan sebanyak 32 peserta didik jurusan busana butuk SMK Negeri 1 Depok, 2 orang ahli materi dan 2 orang ahli media. Keempat validator ahli tersebut sebagai subjek uji coba pada uji alpa, 3 orang peserta didik dengan tiga tingkat kemampuan akademik (tinggi, sedang, rendah) untuk uji coba beta, dan 29 peserta didik pada tanggal evaluasi sumatif. Jenis data kualitatif didapat dari penelitian kelayakan produk multimedia yang dapat digunakan untuk kepentingan pengembangan kualitas produk. Data kuantitatif didapat dari ahli materi, ahli media, dan peserta didik jurusan busana kelas XI. Data tersebut merupakan gambaran untuk menilai kualitas pembelajaran, kualitas materi pembelajaran, kualitas tampilan media, dan kualitas pemograman media. Data tersebut menjadi dasar untuk merevisi produk multimedia. Berikut ini disajikan data yang diperlukan dalam penelitian ini yang dirumuskan berdasarkan kriteria-kriteria peniliaian multimedia yang telah dikembangkan disajikan pada Tabel 2.

Data yang diperoleh berupa komentar, saran, revisi, dan hasil pengamatan pengembang dengan produk multimedia interaktif yang digunakan selama proses pembelajaran dianalisi secara deskriptif kualitatif, dan disimpulkan sebagai masukan untuk pengambang. Sementara, data beru- 
pa skor tanggapan ahli media, ahli materi, dan peserta yang diperoleh melalui kuesioner, dianalisis secara deskriptif kuantitatif dengan menggunakan rumus Sukarjo (2008, p.55) seperti disajikan pada Tabel 4.

Tabel 2. Kisi-Kisi Instrumen Pembelajaran Mendesain Busana

\begin{tabular}{|c|c|c|c|}
\hline No & $\begin{array}{l}\text { Standar } \\
\text { Kompetensi }\end{array}$ & Kompetensi Dasar & Indikator \\
\hline \multirow{5}{*}{1} & \multirow{5}{*}{$\begin{array}{l}\text { Memahami } \\
\text { bentuk busana }\end{array}$} & \multirow{5}{*}{$\begin{array}{l}\text { Mendiskirpsikan } \\
\text { macam -macam } \\
\text { betuk busana } \\
\text { pesta }\end{array}$} & $\begin{array}{l}\text { Mendiskripsikan betuk } \\
\text { busana pesta sesuai } \\
\text { kesempatan }\end{array}$ \\
\hline & & & $\begin{array}{l}\text { Mendiskripsikan } \\
\text { bahan yang digunakan } \\
\text { dalam mendisain } \\
\text { busana pesta }\end{array}$ \\
\hline & & & $\begin{array}{l}\text { Membuat desain } \\
\text { busana pesta sesuai } \\
\text { dengan kesempatan }\end{array}$ \\
\hline & & & $\begin{array}{l}\text { Menerapkan } \\
\text { perwarnaan busana } \\
\text { sesuai teknik } \\
\text { penyelesaian }\end{array}$ \\
\hline & & & $\begin{array}{l}\text { Menerapkan unsur- } \\
\text { unsur dan prinsip } \\
\text { desain busana }\end{array}$ \\
\hline
\end{tabular}

Tabel 3. Kisi-kisi Kriteria Multimedia Interaktif

\begin{tabular}{clll}
\hline No Komponen & Indikator & Jumlah butir \\
\hline 1 & Tampilan & Kualitas animasi & $1,2,3,4,5,16$ \\
& media & Kualitas grafis & $6,8,10,11,13,14$ \\
& & Kualitas suara & 12 \\
& & Kualitas navigasi & $7,9,15$ \\
2 & Pemrograman & Sistem oprasi & $1,2,3,4$ \\
& media & Efisiensi program & $5,6,7,8$ \\
\hline
\end{tabular}

Tabel 4. Kriteria Penilaian

\begin{tabular}{lll}
\hline \multicolumn{1}{c}{ Rumus } & Rentang & Koheren \\
\hline$X>X i+1,8 \mathrm{Sb}$ & $\mathrm{X}>4,2$ & Sangat \\
$X i+0,6 \mathrm{Sbi}<X \leq X i+1,8$ Sbi & $3,4<\mathrm{X} \leq 4,2$ & Baik \\
$X i-0,6 \mathrm{Sbi}<X \leq X i+0,6$ Sbi & $2,6<X \leq 3,4$ & Cukup \\
$X i-1,8$ Sbi $<X \leq X i-0,6$ Sbi & $1,8<X \leq 2,6$ & Kurang \\
$X \leq X i-1,8$ Sbi & $X \leq 1,8$ & Sangat \\
& & Kurang \\
\hline
\end{tabular}

Berdasarkan keterangan pada Tabel 4, untuk mendapatkan data rata-rata hasil penilaian yang akan digunakan untuk menarik kesimpulan digunakan rumus:

$\frac{\text { Total penilaian }}{\sum \text { Aspek yang diamati } \times \sum \text { siswa }}$

Dalam penelitian pengembangan ini ditetapkan nilai kelayakan produk minimal dengan kategori cukup. Sehingga hasil penelitian yang diperoleh baik dari ahli materi, ahli media, maupun pengguna (siswa), jika hasil skor produk multimedia yang diujikan memperoleh nilai minimal (cukup) maka dianggap layak.

\section{Hasil Penelitian dan Pembahasan}

Multimedia interaktif untuk pembelajaran untuk jurusan busana butik yang dikembangkan berdasarkan fakta dan data yang diperoleh dari analisis Kegiatan yang dilakukan memperoleh data yang diperoleh sebagai berikut: (1) menetapkan materi yang akan menjadi produk multimedia. Berdasarkan data yang diperoleh selama studi pustaka melalui studi pustaka, hasil dari analisis data yang diperoleh dapat diketahui bahwa: (a) standar tingkat pencapaian perkembangan peserta didik dalam lingkup mendesain busana dalam lingkup materi unsur-unsur desain betuk siluet dan teknik penyelesain gambar, (b) guru mata pelajaran mendesaian dan ketua jurusan berpendapat bahwa penggunaan multimedia dalam pembelajaran mendesain busana penting untuk mendukung tercapainya kompetensi yang diinginkan. (2) mengidentifikasi karateristik, berdasarkan hasil wawancara yang dilakukan dengan Ketua Jurusan busana butik SMK Negeri 1 Depok dapat diketahui hasil belajar peserta didik dalam pelajaran mendesain masih bervariasi dari yang paling tinggi hingga yang paling rendah sehingga perlu meningkatkan kualitas belajar serta hasil desain yang masih sama yang dibuat peserta didik.

Data yang diperoleh yaitu: (1) SMK Negeri 1 Depok memiliki sarana multimedia yang belum digunakan dengan maksimal dalam pembelajaran seperti satu unit komputer admin, LCD di ruang kelas, lap- 
top yang dibawa guru, (2) belum tersedianya multimedia yang digunakan dalam pembelajaran mendesain busana, pembelajaran masih menggunakan buku terbatas yang ada di perpustakan, (3) guru-guru sudah bisa mengoperasikan komputer atau laptop dalam kegiatan sehari-hari, (4) semua peserta didik SMK Negeri 1 Depok mampu menggunakan komputer atau laptop dalam kegitan belajar sehari-hari.

Pada tahap pengembangan multimedia ini kegiatan yang dilakukan adalah: (1) membuat flowcharts view multimedia pembelajaran multimedia pembelajaran mendesain busana; (2) mengumpulkan bagian-bagian multimedia berupa gambar siluet, gambar busana sesuai unsur-unsur, dan prinsip desain yang diambil dari internet www.facebook.com karya Hayden Williams Illustrations, logo kampus UNY bersumber dari internet (www.google.com/ logokampus/uny), dan rekaman audio game, dan instrumen musik untuk loading awal program; (3) membuat storyboards multimedia pembelajaran mendesain busana untuk menggambarkan bentuk tampilan setiap frame dalam multimedia yang dikembangkan; (4) menggabungkan bagian-bagian multimedia yang telah dikumpulkan dan dikembangkan dengan menggunakan program Adobe Flash CS3 berdasarkan storyboard dan flowchart view. Selanjutunya melakukan analisis kesesuaian pembuatan multimedia dengan flowchart dan storyboard yang direncanakan hal ini untuk memastikan hasil awal pembuatan multimedia sesuai dengan flowchart maupun storyboard yang direncanakan seperti kecocokan warna dan gambar, materi, audio, dan lain-lainnya. Analisis ini juga dilakukan untuk mengetahui jalannya program secara keseluruhan dan pengetesan kebeberapa komputer yang menggunakan Windows yang berbeda namun memiliki spesifikasi yang setara.

Multimedia pembelajaran mendesain busana telah selesai dikembangkan, secara kesluruhan berisi menu-menu sebagai berikut. Pertama, menu mendesain busana yaitu berisi tentang materi bentuk siluet busana, unsur-unsur, prinsip desain, dan teknik penyelesain pada menu ini dibuat dengan model drill agar peserta didik bebas untuk memulai menggunakan media tersebut menyesuaikan kebutuhan mereka. Di produk multimedia ini peserta didik belajar bentuk busana dari bagian luar yaitu siluet busana, menerapkan unsurunsur dan prinsip desain agar desain yang dibuat disesuaikan dengan pemahaman peserta didik. Setelah paham dengan bentuk dan unsur dan prinsip desain, dilanjutkan dengan menu teknik penyelesain berbagai gambar-gambar sesuai dengan teknik penyelesaian yaitu kering, basah, dan mix media ditampilkan di media.

Kedua, menu soal tes menguji pengetahuan kognitif dan piskomotorink peserta didik terhadap pemahaman materi yang telah diberikan agar memotivasi kreatifitas peserta didik, pada menu soal tes peserta didik menjawab pertanyaan dalam bentuk pilihan ganda pada akhir soal terdapat hasil atau nilai. Untuk mendesain dan menu latihan yaitu berupa games puzzle dengan membetuk sebuah gambar menjadi satu rangakaian utuh. Pada menu latihan jika peserta didik berhasil sebelum waktu habis pada games maka terdapat soal latihan yakni membuat desain busana yang mencakup dari materi yang disajikan. Ketiga, menu pengembangan yaitu berisi profil mengenai biodata pengembangan multimedia mendesain busana. Setelah multimedia pembelajaran mendesain busana selesai dikembangkan dan dikemas dalam bentuk CD atau berbentuk File pada flashdisk.

\section{Hasil Uji Coba Produk}

Kegiatan uji coba meliputi uji alpa dan uji beta. Uji alpha dilakukan masingmasing oleh 2 orang ahli media dan 2 orang ahli materi, sedangkan uji beta dilakukan oleh 3 orang siswa kelas XI yang mewakili calon pengguna multmedia interaktif mendesain busana yaitu siswi jurusan busana kelas XI SMK Negeri 1 Depok.

Data yang diperoleh berupa data kuantitatif yaitu skor penilaian ahli dan 
data kualitatif berupa saran yang digunakan untuk memperbaiki produk multimedia. Data uji alpa terdiri dari (1) terdapat dua orang ahli materi dari guru busana. Peneilaian dari ahli materi terhadap keseluruhan instrumen diperoleh skor rata-rata penilain sebesar 4.64 dengan katagori "Sangat Baik" dan diyatakan "Layak" untuk di ujikan; (2) terdapat dua orang ahli miltimedia sebagai ahli media Penilaian dari ahli media terhadap keseluruhan instrumen diperoleh skor rata-rata penilaian yakni 4.16 dan perolehan rata-rata dalam aspek program media sebesar 4.00 dengan katagori "baik" dan dinyatakan "layak" serta dapat dilakukan uji coba berikutnya.

Kemudian data uji coba beta dilakukan dengan 3 orang siswi yang dipilih berdasarkan kemampuan akademik yang direkomendasi guru busana butik yaitu tinggi, sedang, dan rendah untuk mencoba dan mengamati produk yang dihasilkan. Berdasarkan data angket yang disebarkan kepada 3 peserta didik yang menjadi subjek coba dengan penilaian pada aspek materi dan program dapat diketahui bahwa secara media dan materi diperoleh rerata penilaian 4,35 dengan katagori "Sangat Baik". Dapat dilihat pada gambar 16. Sehingga dari segi kualitas media dan materi sudah "Layak" digunakan dalam penelitian sebenarnya. Selanjutnya uji lapangan yang melibatkan 29 siswa busana kelas XI. data uji lapangan terhadap multimedia pembelajaran mendesain busana diperoleh ratarata 4.54 .

\section{Analisis Data}

Validasi terhadap multimedia oleh 2 ahli materi. Validasi dilakukan terhadap komponen penujang materi yang meliputi silabus pembelajaran mendesain busana, lembar konten materi mendesain busana. Pada multimedia interaktif mendesain busana terdapat 2 aspek yang dinilai oleh 2 ahli materi dalam uji alpa yaitu, aspek kualitas materi, dan pembelajaran dan aspek program media dalam materi mendesain busana, dua aspek tersebut dijabarkan kedalam 18 butir. Untuk memberikan gam- baran tentang kulitas materi untuk produk multimedia pembelajaran berdasarkan penilaian dapat dilihat pada Gambar 1.

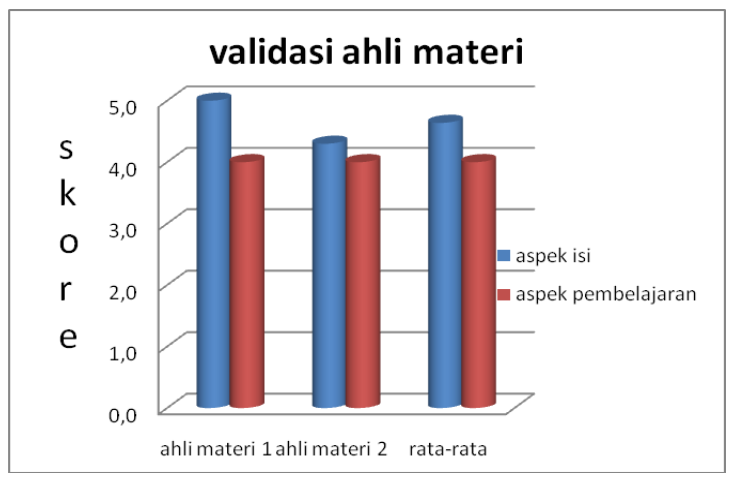

Gambar 1. Validasi Materi Pembelajaran Mendesain Busana

Validasi ahli media dilakukan oleh dua orang dosen. Validasi yang dilakukan oleh kedua ahli media dalam aspek tampilan media dan aspek program media, Untuk memberikan gambaran tentang kelayakan media untuk produk multimedia pembelajaran berdasarkan penilaian dapat dilihat pada Gambar 2.

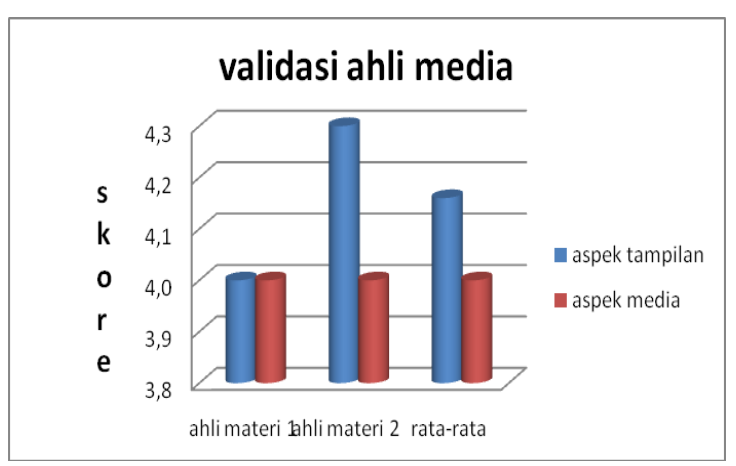

Gambar 2. Validasi Media Pembelajaran Mendesain Busana

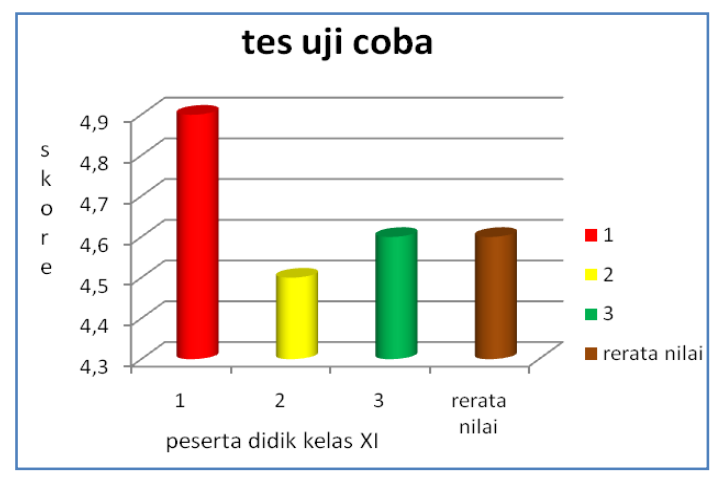

Gambar 3. Tes Uji Coba Peserta Didik 
Analisis pada uji beta dilakukan 3 orang siswa. Tes beta merupakan tes akhir yang sepenuhnya dilakukan oleh siswa sebagai peserta uji coba, dilakukan secara formal sesuai dengan prosedur sebagi berikut: (1) pemilihan peserta didik untuk subjek coba secara acak, (2) penjelasan, (3) pengumpulan informasi kemampuan awal, (4) pengamatan selama menggunakan program, (5) penilaian pembelajaran. (6) angket terkait penggunaan media, (7) perbaikan program. Untuk memberikan gambaran tentang kelayakan pembelajaran desain busana dengan produk multimedia pembelajaran berdasarkan penilaian dapat dilihat pada Gambar 3.

Revisi Produk

Pada revisi produk hali materi dan media memberikan saran yang dapat diperbaiki sebagai berikut: (a) rekomendasi dan saran ahli materi sangat bermanfaat untuk memperbaikai kualitas materi yang disajikan di multimedia. Pada tampilan materi busana antara gambar dan kalimat harus singkron agar mempermudah peserta didik dalam memahami materi dengan cepat. Saran ahli materi 1 dan ahli materi 2 yakni untuk latihan soal di dalam multimedia mendesain lebih diperbanyak agar pemahaman peserta didik dalam mendesain busana lebih muda di mengerti untuk peserta didik dalam mendesain busana sesuai kratifitas dari tampilan gambar-gambar tersebut. Berikut tampilan media sebelum dan sesudah revisi.

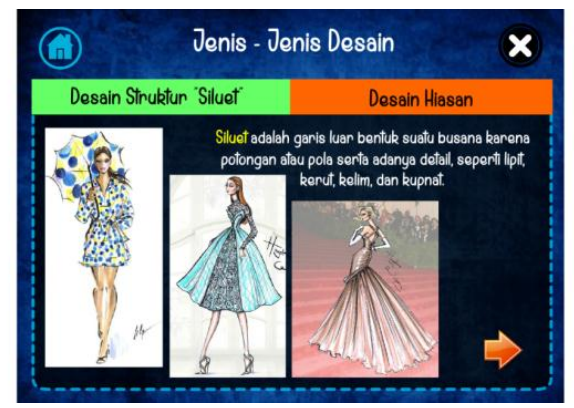

Gambar 4. Tampilan sebelum Revisi

Ahli media menyarakan pada soal latihan untuk pembahasan jawaban soal di berikan tidak hanya memberikan sola lalu mendapat upan balik atau mendapat nilai, namun juga diberikan pembahasan untuk jawaban yang benar agar peserta didik yang belum memahami dapat belajar.

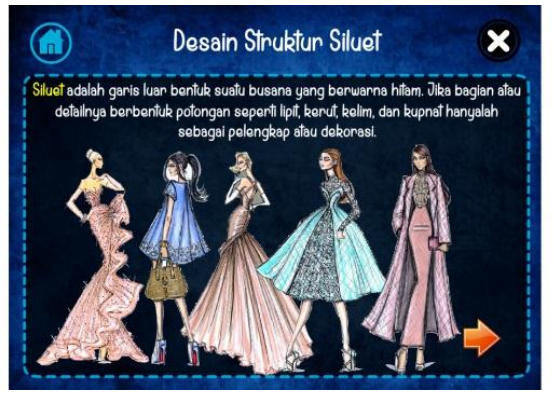

Gambar 5. Tampilan setelah Revisi

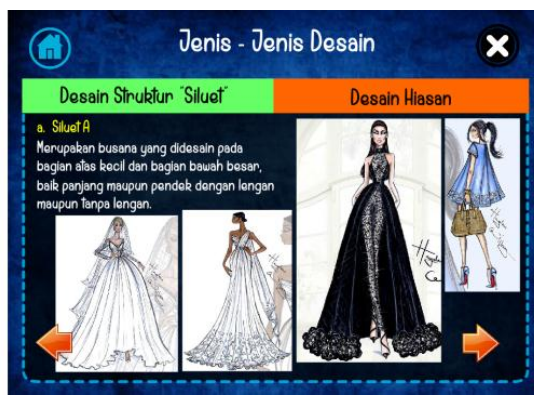

Gambar 6. Tampilan Media Materi Desain Busana sebelum Direvisi

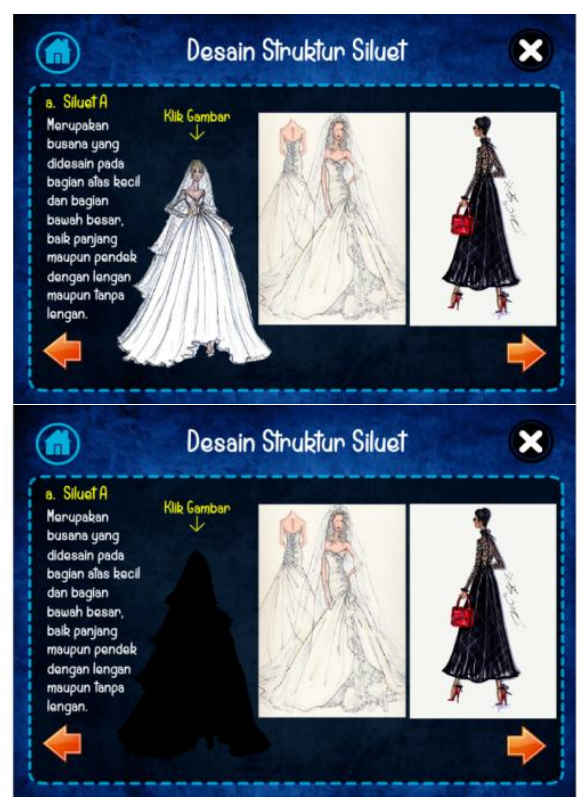

Gambar 7. Tampilan Media Materi Desain Busana setelah Revisi 


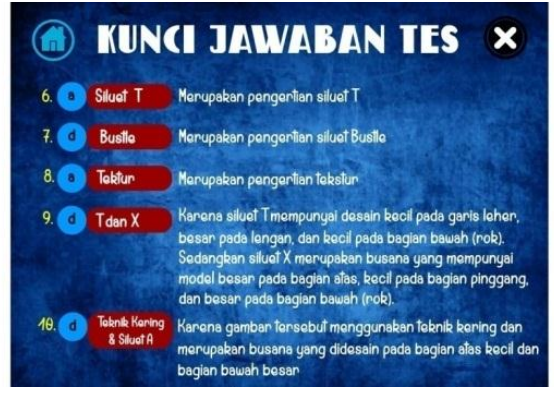

Gambar 8. Tampilan Media untuk Kunci Jawaban soal Tes dangan Pembahasan

Analisis Keefektivian Pembelajran

Evaluasi sumatif dilakukan untuk mengetahui efektivitas peserta didik setelah menggunakan multimedia interaktif mendesain busana. Data hasil belajar ini menjadi rekomendasi bagi pengembang untuk menyimpulkan bahwa produk multimedia interaktif mendesain busana efektif untuk memotivasi kreativitas dalam pelajaran mendesain busana dan hasil t-tes menujukan adanya perbedaan dari peningkatan nilai dengan ( $\mathrm{t}-7.8$ ) dan (sig.000) kurang dari $(0,05)$ yang berarti terdapat perbedaan nilai unjuk kerja sebelum menggunaan produk media.

Selain data penggunaan produk, peserta didik dilihat untuk tes unjuk kerja untuk melihat pemahaman teori dan praktik pembelajaran desain busana yang mencakup kognitif, akfektif, dan peskomotor yang hasil nilai unjuk kerja mendesain busana dari data tersebut menujukan nilai rata-rata pada aspek yang telah ditentukan. Yang pertama aspek cognitive menunjukkan nilai 3,4, kedua aspek affective menunjukkan nilai 3,3, dan ketiga aspek psychomotor menunjukan nilai 3,4. Produk multimedia interaktif untuk pembelajaran busana sangat efektif untuk peserta didik dalam mendesain busana.

\section{Simpulan dan Saran}

Berdasarkan hasil analisis data penelitian dan pembahasan pengembangan multimedia pembelajaran mendesain busana di SMK Negeri 1 Depok, dapat disimpulkan sebagai berikut: (1) multimedia pembelajaran yang dikembangkan dinilai layak digunakan ditinjau dari aspek media, materi desain busana, dan penilanian peserta didik; (2) produk multimedia interaktif pembelajaran mendesain busana yang berhasil dikembangkan ini telah layak dihasilkan dari aspek tampilan dan pemograman oleh ahli media memperoleh nilai 4.54 dengan kategori layak, aspek materi oleh ahli materi memperoleh nilai 4,64 dengan kategori layak, dan hasil uji coba pada peserta memperoleh nilai 4,35 dengan kategori layak; (3) produk multimedia interaktif pembelajaran mendesain busana yang berhasil dikembangkan ini telah efektif digunakan dalam pembelajaran mendesain busana pada peserta didik dan pengajar jurusan busana.

Berdasarkan hasil penelitian yang sudah disajikan dapat disarankan: (1) peserta didik dapat memanfaatkan multimedia pembelajaran mendesain ini untuk pembelajaran mandiri agar dapat mengenal konsep desain secara detail. Karena kemampuan peserta didik yang berbedabeda dan gaya mendesain busana yang berbeda antar peserta didik; (2) Bagi guru hendaknya mengembangan multimedia pembelajaran mendesain busana dan menjadi bahan pembelajaran serta pemanfaatan multimedia yang sesuai dengan waktu dan tujuan dalam menyampaikan materi mendesain busana.

Tabel 5. Hasil Uji T

Paired Differences

\begin{tabular}{|c|c|c|c|c|c|c|c|}
\hline \multirow[t]{2}{*}{ Mean } & \multirow{2}{*}{$\begin{array}{c}\text { Std. } \\
\text { Deviation }\end{array}$} & \multirow{2}{*}{$\begin{array}{l}\text { Std. Error } \\
\text { Mean }\end{array}$} & \multicolumn{2}{|c|}{$\begin{array}{l}\text { 95\% Confidence interval of } \\
\text { the difference }\end{array}$} & \multirow[t]{2}{*}{$\mathrm{t}$} & \multirow[t]{2}{*}{$\mathrm{df}$} & \multirow[t]{2}{*}{ Sig. (2-tailed) } \\
\hline & & & lower & upper & & & \\
\hline 3.79310 & 9,41647 & 1,74860 & 7,37494 & 0,21127 & $-7,888$ & 28 & ,000 \\
\hline
\end{tabular}




\section{Daftar Pustaka}

AECT, The Definiton Of Educational Technology and Domains of the Filed, (1994). Washington, DC. Diterjemahkan: Miarso, Y \& Prawiradilaga, S.D. Jakrata: (IPTPI)

Alessi, S.M. \& Trollip S.R. (2001). Multimedia for learning, methods and development. Boston: Allyn and Bacon-A Pearson Education Company.

Arsyad, A. (2009). Media pembelajaran. Jakarta: PT Rajawali Press

Bestari, A. G. (2011). Menggambar busana dengan teknik kering. Sleman: KTSP

Blandine, L. (2014). Fashion design lookbook. Guangdong, China: USA Inc

Budiningsih, A. (2005). Belajar dan pembelajaran. Jakarta: Rineka Cipta

Degeng, S.N. (2013). Ilmu Pembelajaran. Bandung: Arasmedia.

Direktorat Pembinaan SMK, (2006) Penyelenggaraan sekolah menengah kejuruan, Departemen pendidikan nasional.

Dwiningrum, Astuti I.S, (2013) Metode Penelitian Pendidikan. Yogyakarta: UNY Press

Miarso, Y. (2007). Menyemai benih teknologi pendidikan, Jakarta: Kencana.
Rusdewanti, P., \& Gafur, A. (2014). Pengembangan media pembelajaran interaktif seni musik untuk siswa smp. Jurnal Inovasi Teknologi Pendidikan, 1(2), 153-164. doi:http://dx.doi.org/10.21831/tp. v1i2.2526

Smaldino, S.E., Russel, J. D. , Molenda, M., (2005). Instructional technology and media for learning. (8 edition). New Jersey: Pearson Merrill Prentice Hall.

Sukarjo. (2006). Kumpulan materi evaluasi pembelajaran. Yogyakarta. Program Pascasarjana

Sumaryati, Catri \& Winarti Z. (2013) Dasar desain 2. Kementerian Pendidikan dan Kebudayaan.

Verecio, Rommel L. ( Juni 2014) Students' evaluation of an interactive multimedia courseware. Diambil pada tanggal 20 Februari 2015, dari http://www.ijern.com/journal/Jun e-2014/02.pdf

Winarno, Yasid, Marzuki \& Alimah (2012), Teknik evaluasi multimedia pembelajaran, genius Prima

Yudhiantoro, D. (2006). Macromedia flash professional 8. Jakarta: Andi offset 